46. Shah, M. M., Zhang, S. and Liu, T., Whitefly, host plant and parasitoid: a review on their interactions. Asian J. Appl. Sci. Eng., 2015, 4, 48-61.

47. Ellango, R. et al., Distribution of Bemisia tabaci genetic groups in India. Environ. Entomol., 2015, 44, 1258-1264.

48. Singh, S. T. et al., Diversity and phylogenetic analysis of endosymbiotic bacteria from field caught Bemisia tabaci from different locations of North India based on $16 \mathrm{~S}$ rDNA library screening. Infect. Genet. Evol., 2012, 12, 411-419.

49. Fondong, V. N., Geminivirus protein structure and function. Mol. Plant Pathol., 2013, 14, 635-649.

50. Khan, Z. A. and Khan, J. A., Characterization of a new begomovirus and betasatellite associated with chilli leaf curl disease in India. Arch. Virol., 2017, 162, 561-565.

51. Nawaz-ul-Rehman, M. S., Briddon, R. W. and Fauquet, C. M., A melting pot of Old World begomoviruses and their satellites infecting a collection of Gossypium species in Pakistan. PLoS ONE, 2012, 7, e40050.

52. Islam, M. N., Sony, S. K. and Borna, R. S., Molecular characterization of mungbean yellow mosaic disease and coat protein gene in mungbean varieties of Bangladesh. Plant Tissue Cult. Biotechnol., 2012, 22, 73-81.

ACKNOWLEDGEMENTS. This work was supported by the Japan International Cooperation Agency under the project 'Maximization of soybean production in Madhya Pradesh' (2012-2016). We thank K. Taniwaki, S. S. Tomar and S. K. Rao for encouragement and support. We also thank M. Ohnuki for his early guidance and suggestions.

\section{Urban sustainability analysis of Solan district, Himachal Pradesh, India}

\section{Jyotsana Pandit ${ }^{1,2, *}$, S. K. Bhardwaj ${ }^{1}$ and Anish Kumar Sharma ${ }^{2}$}

${ }^{1}$ Department of Environmental Science, University of Horticulture and Forestry, Nauni, Solan 173 230, India

${ }^{2}$ School of Sciences, P.P. Savani University, Surat 394 125, India

Urbanization is one of the most significant global trends of modern times, driving and driven by multiple social, economic and environmental processes. Due to uncontrolled urbanization, there is rapid environmental degradation which causes many problems. Scientific assessments can help provide solutions by considering the local realities. Numerous assessment strategies have been suggested such as emerge analysis, material flow analysis, data development analysis

\footnotetext{
*For correspondence. (e-mail: jyotsanapandit@gmail.com)
}

and ecological footprint analysis (EFA). EFA has been implemented as a useful analytical and planning tool for assessing urban sustainability in numerous cities. The aim of this study is to use one of the EFA components, viz. built-up land footprint $\left(\mathrm{EF}_{\text {built-up }}\right)$ to evaluate the urban sustainability of Solan district, Himachal Pradesh (HP), India, in terms of settlements. The study concludes that $\mathbf{E F}_{\text {built-up }}$ of Solan district, HP, exceeds its biocapacity, resulting in an ecological deficit. Therefore, element of built-up land in Solan district is considered as an unsustainable system.

Keywords: Biocapacity, built-up land footprint, ecological footprint analysis, ecological deficit, urban sustainability.

THE world is increasingly becoming urbanized. About $65 \%$ of the world's population is expected to live in cities by 2025 (ref. 1). Excessive urban sprawl is the source of many problems such as air pollution, crime, housing, noise pollution, traffic jam, shortage of clean drinking water as well as energy ${ }^{2}$. Since the end of the 19 th century, the problems posed by modern urban development have emerged in the environmental, social and economic spheres, which have made these communities unstable and forced experts to look for alternative urban development patterns. Modern-day lifestyles are exploiting many natural resources, polluting the environment, increasing social inequality, building tropical islands and causing climate change. In this regard, the term 'sustainability' was first developed by the United Nations in the Brundtland Commission Report, which defines sustainable development as one that meets current needs without compromising the ability of future generations to meet their needs ${ }^{3}$. The problem of achieving sustainable urban development is thus an important challenge. Measuring urban sustainability is an engine of social and economic development, but at the same time focusing on environmental issues is a major challenge for environmental managers and decision-makers ${ }^{4}$.

Urban sustainability is defined as the process by which measurable long-term social development can be achieved through actions in the environment, economic and social magnitude. The use of sustainability indicators is increasingly needed to achieve sustainability ${ }^{5}$. Sustainability indicators are the solid basis for regular and long-term monitoring of progress towards achieving strategic developmental goals and evaluation of various forms of sustainability ${ }^{6}$. They provide past and present trends for any particular problem, and serve as a supportive tool for future decisions ${ }^{6}$. They are the tools needed to develop a strategy and for policy development, to provide a picture of the three dimensions of sustainable urban development: social, economic and environmental. They need to assess the state of sustainable urban development in order to support urban environmental 
planning, construction and management. There are three indicators of sustainability, namely economic, social and environmental. Economic indicators emphasize local financial stability. Social indicators focus on participating in the democratic process. Environmental indicators promote sustainable use of resources and include air quality, emission of greenhouse gases, water, land, waste and the environment ${ }^{7}$.

The aim of the present study is to assess the sustainability of cities in Solan district, Himachal Pradesh (HP), India, using ecological footprint indicator. It is an example of a sustainability indicator with an environmental focus. The ecological footprint is a measure of environmental impacts of modernization that surpass the surrounding regions. Ecological footprint analysis (EFA) is defined as 'a synthetic method to trail human impacts on the regenerative capacity of an environmental system through identifying the amount of bioproductive land required to support average annual consumption and waste production of a given entity under prevailing technologies ${ }^{8}$. It has been implemented as a useful analytical and planning tool for assessing urban sustainability in many cities. Ecological footprint accounting is the total sum of six components, namely cropland, carbon land, grazing land, fishing grounds, forest land and built-up land. These components together provide a measure of the ecological footprint ${ }^{9}$. In the present study, built-up land component

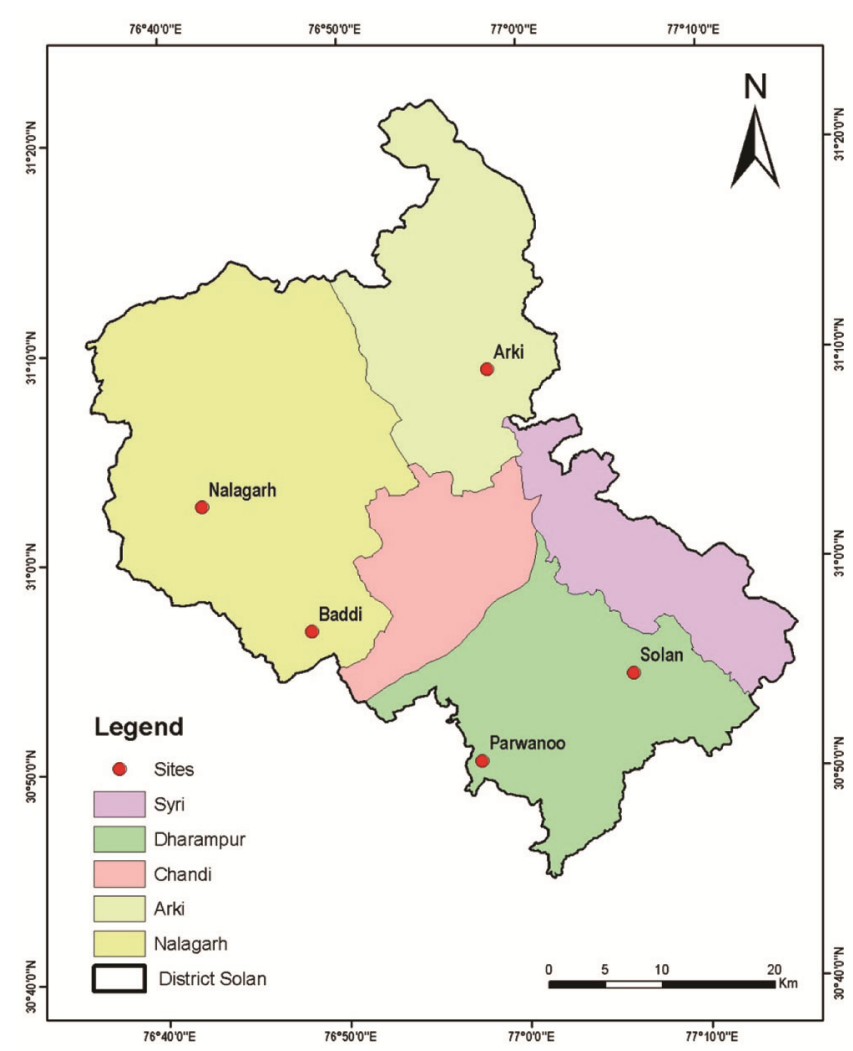

Figure 1. Map showing the study area in Solan district, Himachal Pradesh, India. (built-up area for housing, infrastructure, transportation and industrial production) is used to assess the sustainability of different urban areas of Solan district, HP. Solan was chosen for the study because it is one of the fastest growing districts of HP, dominated by various commercial and industrial activities, and road networks. It is a state-owned industrial centre with migrant populations. In addition, there is proliferation of many small and medium enterprises across the district. In the recent past, Solan district has experienced the highest level of urbanization $(18.26 \%)$ after Shimla in HP, due to migration of rural population to cities in search of jobs, and better facilities like education. The current urban areas of the district (Arki, Baddi, Nalagarh, Parwanoo and Solan) are home to about $17.7 \%$ of the state.

The study was conducted during 2019 in the urban areas of Solan district, HP, that range between $30^{\circ} 44^{\prime} 53^{\prime \prime}-31^{\circ} 22^{\prime} 01^{\prime \prime} \mathrm{N}$ lat. and $76^{\circ} 36^{\prime} 10^{\prime \prime}-77^{\circ} 15^{\prime} 14^{\prime \prime} \mathrm{E}$ long. (Figure 1). The district is a 'gateway' of HP, bordering the southern and western states of Haryana and Punjab respectively. HP has a total geographical area of $1936 \mathrm{~km}^{2}$ with a population of 580,320 (ref. 10), which is projected to increase to 665,671 by 2021 . The physical environment of the region is rapidly changing due to more urban migration, and trade and multiculturalism over the years.

In order to conduct the analysis of built-up land footprint of Solan district, HP, data on built-up land area and population of different urban areas were procured from the official certified records maintained by Census of India, whereas data on yield and equivalence factors were derived from national footprint accounts.

The built-up land footprint is defined as the area of land covered by human infrastructure such as transportation, housing, industrial structures and reservoirs for hydropower'. It is calculated following the method outlined by Kandil et al. ${ }^{11}$.

$$
\mathrm{EF}_{\text {built-up }}=A \times \mathrm{EQF} \times \mathrm{YF} / N \text {, }
$$

where $\mathrm{EF}_{\text {built-up }}$ is the built-up land footprint/ecological footprint of built-up land ( $\mathrm{g} \mathrm{ha}$ ), $A$ the area of built-up land (ha), EQF the equivalence factor of built-up land (g ha), YF the yield factor of built-up land and $N$ is the population.

Built-up land biocapacity (BC) refers to the capacity of a given biologically productive area to generate an on-going supply of renewable resources and absorb its spillover wastes. When measuring the biocapacity of a given land-use type, it is general practice to allot $12 \%$ of accessible supply land to secure domestic biodiversity. $\mathrm{BC}$ is calculated using the formula outlined by Kandil et al. ${ }^{11}$.

$$
\mathrm{BC}_{\text {built-up }}=A \times \mathrm{EQF} \times \mathrm{YF}(100-12 \%) / N,
$$

where $\mathrm{BC}_{\text {built-up }}$ is the total biocapacity of built-up land (g ha), $A$ the total available supply in a given year for 
built-up land (ha), EQF the equivalence factor of a given land type ( $\mathrm{g}$ ha), YF the yield factor of built-up land and $\boldsymbol{N}$ is the population.

Ecological deficit $\left(\mathrm{EF}_{\mathrm{D}}\right)$ is measured as the difference between ecological footprint and biocapacity. If the ecological footprint surpasses biocapacity, the framework is considered unsustainable; if biocapacity surpasses footprint, it is considered sustainable.

$$
\mathrm{EF}_{\mathrm{D}}=\mathrm{EF}-\mathrm{BC}
$$

where $\mathrm{EF}_{\mathrm{D}}$ is the ecological deficit, $\mathrm{EF}$ the ecological footprint by consumption categories and $\mathrm{BC}$ is the biocapacity.

Yield factors reflect the relative productivity of national and world average hectares of a given land-use type. Each country in each year has a yield factor for each land-use type. Equivalence factors reflect the relative productivity of world average hectares of different landuse types. They are the same for all countries, and change slightly from year to year. For 2019, yield and equivalence factor for built-up land was 1.08 and $2.51 \mathrm{~g} \mathrm{ha} \mathrm{ha}^{-1}$ respectively ${ }^{12}$.

It is evident from the data presented in Table 1 that the total and per capita built-up land footprint with respect to different urban areas are 6771.553 and $0.464 \mathrm{~g}$ ha respectively. The total builtup land footprint of different urban areas in Solan district, HP, ranged from 398.604 to $2289.978 \mathrm{~g}$ ha. The urban area-wise trend was: Parwanoo (2289.978 g ha) $>$ Baddi (1891.375 g ha) $>$ Solan (1681.383 g ha) > Nalagarh (510.213 g ha) $>$ Arki (398.604 g ha). The highest built-up land footprint of Parwanoo (2289.978 g ha) may be ascribed to rapid

Table 1. Urban area-wise built-up land footprint $\left(E_{\text {built-up; }} g\right.$ ha) in Solan district, HP, India

\begin{tabular}{lrc}
\hline Urban area & Per urban area $\mathrm{EF}_{\text {built-up }}$ & Per capita $\mathrm{EF}_{\text {built-up }}$ \\
\hline Arki & 398.604 & 0.111 \\
Baddi & 1891.375 & 0.055 \\
Nalagarh & 510.213 & 0.042 \\
Parwanoo & 2289.978 & 0.221 \\
Solan & 1681.383 & 0.035 \\
Total & 6771.553 & 0.464 \\
\hline
\end{tabular}

Table 2. Urban area-wise built-up land biocapacity $\left(\mathrm{BC}_{\text {built-up; }} \mathrm{g}\right.$ ha) in Solan district, HP

\begin{tabular}{lrc}
\hline Urban area & Per urban area $\mathrm{BC}_{\text {built-up }}$ & Per capita $\mathrm{BC}_{\text {built-up }}$ \\
\hline Arki & 350.771 & 0.098 \\
Baddi & 1664.410 & 0.048 \\
Nalagarh & 448.987 & 0.037 \\
Parwanoo & 2015.181 & 0.195 \\
Solan & 1479.617 & 0.031 \\
Total & 5958.966 & 0.409 \\
\hline
\end{tabular}

development in the area. Further, higher population density, waste generation, material and energy consumption might have added to increased built-up land footprint. Whereas lowest built-up land footprint of Arki might be due to relatively lesser developmental activities and population density in the region. The per capita built-up land footprint of different areas ranged from 0.035 to $0.221 \mathrm{~g}$ ha capita $^{-1}$ and followed the order Parwanoo $\left(0.221 \mathrm{~g}\right.$ ha capita $\left.^{-1}\right)>$ Arki $\left(0.111 \mathrm{~g}\right.$ ha capita $\left.^{-1}\right)>$ Baddi $\left(0.055 \mathrm{~g}\right.$ ha capita $\left.^{-1}\right)>$ Nalagarh $\quad\left(0.043 \mathrm{~g} \mathrm{ha} \mathrm{capita}^{-1}\right)>$ Solan $\left(0.035 \mathrm{~g}_{\text {ha }}\right.$ capita $\left.^{-1}\right)$. The per capita built-up land footprint did not exhibit any particular trend, because different towns have varied geographical areas and do not accommodate population proportional to their area.

Table 2 shows that total and per capita built-up land biocapacity with respect to different urban areas are 5958.966 and $0.409 \mathrm{~g}$ ha respectively. The total built-up land biocapacity of different urban areas ranged from 350.771 to $2015.181 \mathrm{~g} \mathrm{ha}$, and followed the trend: Parwanoo (2015.181 g ha) $>$ Baddi $\quad(1664.410 \mathrm{~g} \mathrm{ha})>$ Solan $(1479.617 \mathrm{~g} \mathrm{ha})>$ Nalagarh $(448.987 \mathrm{~g}$ ha $)>$ Arki (350.771 g ha). The highest built-up biocapacity of Parwanoo might be due to its maximum built-up land area and the lowest for Arki due to its minimum built-up land area. The per capita built-up biocapacity of different areas ranged from 0.031 to $0.195 \mathrm{~g}$ ha capita ${ }^{-1}$ and was in the order: Parwanoo (0.195 $\mathrm{g}_{\text {ha }}$ capita $\left.^{-1}\right)>$ Arki $(0.098$ $\left.\mathrm{g}_{\text {ha capita }}{ }^{-1}\right)>$ Baddi $\quad\left(0.048 \mathrm{~g}\right.$ ha capita $\left.^{-1}\right)>$ Nalagarh $\left(0.037 \mathrm{~g}\right.$ ha capita $\left.^{-1}\right)>$ Solan $\left(0.031 \mathrm{~g}\right.$ ha capita $\left.^{-1}\right)$. No trend was observed in built-up land biocapacity because of varied population levels which were not proportional to the geographical area.

Table 3 shows that total and per capita ecological deficit of different urban areas are 814.434 and $0.056 \mathrm{~g}$ ha respectively. A scrutiny of the data reveals that the built-up land footprint of different urban areas exceeds the biocapacity. This indicates that different urban areas need huge built-up land than they hold in order to back up their urban activities, which is an indication of the loss and degradation of natural capital, and accumulation of waste in the regions. The total ecological deficit of different urban areas ranged from 47.832 to $276.645 \mathrm{~g}$ ha (Figure 2) and followed the trend: Parwanoo (276.645 $\mathrm{g} \mathrm{ha})>$ Baddi (226.965 g ha) $>$ Solan (201.766 g ha) $>$ Nalagarh

Table 3. Urban area-wise ecological deficit $\left(\mathrm{EF}_{\mathrm{D}} ; \mathrm{g}\right.$ ha) in Solan district, HP

\begin{tabular}{lrc}
\hline Urban area & Per urban area $\mathrm{EF}_{\mathrm{D}}$ & Per capita $\mathrm{EF}_{\mathrm{D}}$ \\
\hline Arki & 47.832 & 0.013 \\
Baddi & 226.965 & 0.007 \\
Nalagarh & 61.226 & 0.005 \\
Parwanoo & 276.645 & 0.027 \\
Solan & 201.766 & 0.004 \\
Total & 814.434 & 0.056 \\
\hline
\end{tabular}




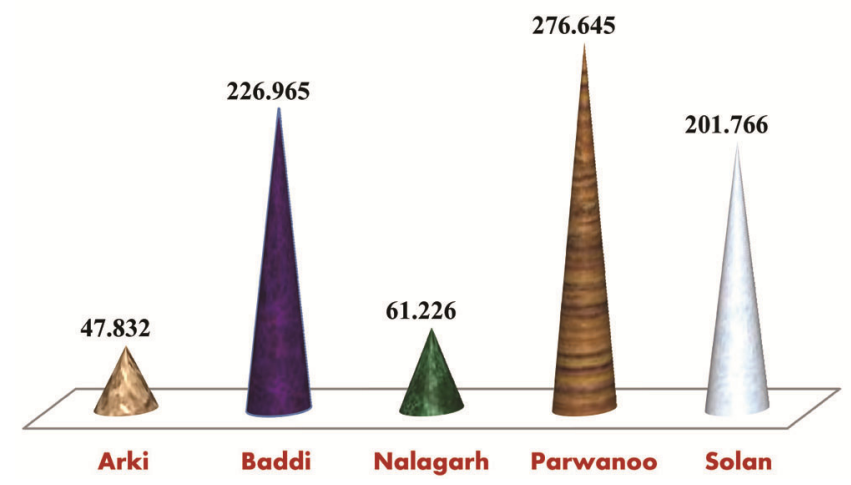

Figure 2. Ecological deficit ( $\mathrm{g}$ ha) of different urban areas in Solan district, HP.

(61.22 g ha) $>$ Arki (47.832 g ha; Figure 2). The highest ecological deficit of $276.885 \mathrm{~g}$ ha in Parwanoo indicates that in this region natural resources are being exploited at a higher rate than they are being produced, due to increased urbanization and associated changes in lifestyle. Further, this may be attributed to the largest concentration of industries and high-income segments of the population responsible for the bulk of resource consumption, and increasing pressure on natural capital in the region. Whereas the lowest ecological deficit of $47.832 \mathrm{~g}$ ha in Arki may be due to lesser developmental activities in the region. The per capita ecological deficit of different urban areas varied from 0.004 to $0.027 \mathrm{~g} \mathrm{ha} \mathrm{capita}^{-1}$ and followed the order: Parwanoo $\left(0.027 \mathrm{~g} \mathrm{ha} \mathrm{capita}^{-1}\right)>$ Arki $\left(0.013 \mathrm{~g}\right.$ ha capita $\left.^{-1}\right)>$ Baddi $\left(0.007 \mathrm{~g} \mathrm{ha} \mathrm{capita}^{-1}\right)>$ Nalagarh $\left(0.005 \mathrm{~g}_{\text {ha capita }}{ }^{-1}\right)>$ Solan $\left(0.004 \mathrm{~g}_{\text {ha capita }}{ }^{-1}\right)$. No pattern was followed in developed land impression in light of changed population levels, which was not proportional to geographical area. The per capita ecological deficit did not display any specific pattern, on the grounds that various towns have different geographical areas and their population has not expanded relative to these areas.

The findings of this study indicate a high total $\mathrm{EF}_{\text {built-up }}$ compared to $\mathrm{BC}_{\text {built-up }}$ for Solan district, HP. Further, the ecological deficit also points towards unsustainability, indicating that the region needs additional bioproductive built-up land than it holds in order to back up its urban activities. Therefore, to sustain urbanization in the district, the focus should be on the development of smart cities through urban renewal and adoption of environment-friendly measures. Furthermore, a cohesive sustainability plan should be developed for district that acknowledges the unique characteristics of the region and its connections to global processes, while supporting periodic renewal measures to address major environmental, social and economic changes.

Conflict of interest. The authors declare that there is no conflict of interest.
1. Schell, L. M. and Ulijaszek, S. J., Urbanism, Health and Human Biology in Industrialized Countries, Cambridge University Press, London, UK, 1999, pp. 59-60.

2. Vandijk, M. and Mingshun, Z., Sustainability indices as a tool for urban managers, evidence from four medium-sized Chinese cities. Environ. Impact Assess., 2005, 25(6), 667-688.

3. Partridge, E., Social sustainability: a useful theoretical framework. In Social Sustainability, Australasian Political Science Association Annual Conference, Dunedin, New Zealand, 2009.

4. Moussiopoulos, N., Achillas, C., Vlachokostas, C., Spyridi, D. and Nikolaou, K., Environmental, social and economic information management for the evaluation of sustainability in urban areas: a system of indicators for Thessaloniki, Greece. Cities, 2010, 27(5), 377-384.

5. Repetti, A. and Desthieux, G., A relational indicator set model for urban land-use planning and management: methological approach and application in two case studies. Landsc. Urban Plann., 2006, 77(11), 196-215.

6. Hernández, M. S. and De, H. M. J., Indicators of urban sustainability in Mexico. Theor. Empirical Res. Urban Manage., 2010, 7(16), 46-60.

7. Kotharkar, R., Bahadure, S., Bahadure, P. and Surawar, M., Measurability for sustainable urban development: concept to application. ABACUS J. Archit. Conserv. Urban Stud., 2011, 7(2), $72-87$.

8. Monfreda, C., Wackernagel, M. and Deumling, D., Establishing national natural capital accounts based on detailed ecological footprint and biological capacity accounts. Land Use Policy, 2004, 21(1), 231-246.

9. Wilson, J. and Anielski, M., Ecological footprints of Canadian municipalities and regions. Canadian Federation of Canadian Municipalities, Canada, 2005, p. 59.

10. GoI, Census of India 2001: size, growth and distribution of population in India. Ministry of Home Affairs, Government of India, 2011, pp. 1-60.

11. Kandil, R. A., Sarhan, A. and Abdelgalil, R. E., Urban ecological footprint analysis as an evaluation tool for sustainability: analysis of the built-up land footprint of Alexandria city, Egypt. In The Sustainable City XIII, WIT Press, Rome, Italy, 2019, pp. 271281.

12. Lin, D. et al., Working Guidebook to the National Footprint and Biocapacity Accounts, Global Footprint Network, Oakland, CA, USA, 2019.

ACKNOWLEDGEMENT. We thank the Department of Environment Science, YSP University of Horticulture and Forestry, Nauni, Solan, for providing the necessary facilities.

Received and accepted 17 February 2021

doi: $10.18520 / \mathrm{cs} / \mathrm{v} 120 / \mathrm{i} 7 / 1246-1249$ 